\title{
ELECTRICAL CONSTRUCTION KITS AND THEIR INFLUENCE ON TEACHING
}

\author{
Čestmír SERAFÍN
}

\begin{abstract}
The efficiency of the education is variable, which is very difficult to measure, influenced by a variety of input components-students, teachers, school curricula, the school's internal and external factors. Generally, it is necessary to assess the degree of efficiency of the functioning of the training to carry out a comparison of the rate variables describing the inputs with the same intensity of quantities characterizing the outputs. This article deals with the intermediate results of the research evaluating the scope of the efficiency of the functioning of the educational process in the field of education and training of the "man and the world of work" in the context of electrical engineering. Research to check whether the electrical construction kits influence on teaching and that their use reflects the results of the pupils. The objects of research were pupils and subject of research is their knowledge and understanding.
\end{abstract}

Key words: education, efficiency, electrical construction kits, project training, subject didactics.

\section{ELEKTROTECHNICKÉ STAVEBNICE A JEJICH VLIV NA VÝUKU}

Resumé: Efektivita vzdělávání je proměnná, která je velice obtížné měřitelná, ovlivněna řadou vstupních komponent -žáci, učitelé, školní kurikulum, atd. Obecně neříci, že efektivita je nezbytná pro hodnocení účinnosti fungování vzdělávání. Tento článek pojednává o průběžných výsledcích výzkumu hodnocení rozsahu účinnosti fungování vzdělávacího procesu v oblasti Člověk a svět práce v kontextu elektrotechniky. Výzkum je zaměřen na otázky, zda elektrotechnické stavebnice mají vliv na výuku a zda jejich použití se odráží ve výsledcích žáků.

Klićcová slova: vzdělávání, efektivita, elektrotechnické stavebnice, oborová didaktika, projekt vzdělávání.

\section{Introduction}

The efficiency of education it is a construct with many processes and subprocesses is a quantity that is very difficult to measure, influenced by a number of input components students, teachers, curriculum documents, internal and external factors of the school. In the most general level, the efficiency of education is defined as success in meeting educational goals (1), or more efficient spending of forces and means for implementation of the Education and Training (2).

The basic areas of efficiency include professional management, and quality of the teaching staff, vision and goals, school climate, communication, cooperation ability, resources, funding, curriculum or educational attainment. To assess the efficiency is therefore necessary to consider a large number of indicators, which are often measurable only with difficulty. Therefore, you can meet with different sub- types of efficiencies; the advantage is precisely their specificity and the resulting easier and more objective measurability.

\section{Measuring the effectiveness of education}

To measure efficiency, it is important to any particular system of teaching work with some effectiveness. Generally, it is necessary to determine the degree of efficiency of functioning of any system to compare the rate magnitudes characterizing the degree of input variables characterizing the same outputs. As is the case in natural and technical sciences, the term used where efficiency $\eta$ (efficiency), which is defined as follows (3):

$$
\eta=\mathrm{P} / \mathrm{P}_{0}=\mathrm{E} / \mathrm{W}
$$

Where equipment efficiency $\eta$ (the system) is defined as the ratio power output $\mathrm{P}$ and $\mathrm{P}_{0}$ machine (system) or a share of the work $\mathrm{W}$ done in a certain period of time and energy E supplied to the machine (system) in the same timeframe.

In economic and social sciences is the efficiency E expressed by equation (4):

$$
\mathrm{E}=\text { output } / \text { input }=\text { effect } / \text { cost }
$$


When generalization is possible both to understand the efficiency of using the term in both social and natural sciences as well, but with one major difference - this is the interpretation of results. The educational process efficiency value $\mathrm{E}=1$ would mean that the pupil is in the process learned nothing new. Quality of its output level of knowledge is the same with the level of knowledge and quality of input process enriched him nothing. This is certainly not a satisfactory result, ignoring the possibility that part of knowledge, especially if not properly secured, could also be forgotten (tuition only then compensate for the influence of the process of forgetting). While in the case of physical nature is the same value, the efficiency $\eta=1$, the limit which can never be achieved. Although the efficiency $\eta$ and $E$ efficiency is values in terms of definition analogous to the relationship, their numerical values are as indicators of the quality of the different functions of explanatory value (3).

The basic characteristics that can be considered as signs of the efficiency of education can be considered (5):

- complex nature of the action - within the educational process are purposefully and continuously developed all aspects intellectual , but also philosophical and moral;

- the nature of individual action - within the educational process is to secure optimal development of pupils;

- the methods and means - in the educational process is learned methods and rational and productive means of study;

- systematic and logical structure - the educational process is organized to meet the conditions of orderliness and rationality;

- a comprehensive and harmonious development of pupils - within the educational process is used by the system of teaching methods that develop individual pages of intellect and personality of students.

\section{Teaching efficiency project}

To determine the efficiency of teaching project, we chose the teaching of practical activities for primary school within the Man and the world of work using electrical construction kits, and without them. In the current situation where electrical kits are a number of reasons used in basic degree of Education, is particularly appropriate to use this fact to determine the effectiveness of teaching. When the survey was based on the assumption that if the electrical kit should have any effect on teaching, demonstrated by the fact that the results of teaching. It is therefore working hypothesis formulated embryo: Use of electrical construction kits has a positive impact on the effectiveness of teaching. They also take into account the area of teaching project. Based reasoning is the assumption that learning takes place effectively if such methods are chosen that allow students to apply the most learned in real situations (6). With close relationship with the student's real life also a way of learning more fun and are motivated to learn. In the implementation of research, we therefore tried to emphasize with students:

- interconnectedness of knowledge from different subjects;

- motivation and activation;

- connectivity with reality;

- development work and study habits;

- work in teams.

Based on the above were determined following research objectives - the main aim was to experiment with the implementation of project learning supported by electro kit and detection efficiency realized this way of teaching. The objects of research were students and research were the subject of their knowledge and understanding. The group of respondents consisted of four classes of students eighth and ninth grade (121 students in two classes of two years). In the experimental class (E1, E2) were determined with a lower -class secondary school and a control class (K1, K2) were intended contrast class with better academic performance. Based on these values were determined the mean and variance values (Table 1).

Table 1 Input data

\begin{tabular}{|l|r|r|r|r|}
\hline & \multicolumn{2}{|c|}{8 . grade } & \multicolumn{2}{c|}{ 9. grade } \\
\hline Class & K1 & \multicolumn{1}{c|}{ E1 } & K2 & \multicolumn{1}{c|}{ E2 } \\
\hline $\begin{array}{l}\text { Number of pupils } \\
n\end{array}$ & 31 & 31 & 30 & 29 \\
\hline Arithmetic mean & 2,51 & 3,10 & 2,07 & 2,80 \\
\hline Median $x$ & 3 & 4 & 3 & 3 \\
\hline Variance $s^{2}$ & 0,65 & 0,47 & 0,80 & 0,50 \\
\hline $\begin{array}{l}\text { Standard } \\
\text { deviation } s\end{array}$ & 0,81 & 0,69 & 0,89 & 0,71 \\
\hline Maximum & 4 & 4 & 4 & 4 \\
\hline Minimum & 1 & 1 & 1 & 1 \\
\hline
\end{tabular}

The next step is to test the significance of difference between two variances - whether or not statistically significant compared with each other files. An obvious prerequisite for the use of 
F - test is approximately normally distributed files. So for the 8 th volume is $\mathrm{F}=\mathrm{s}_{1}{ }^{2} / \mathrm{s}_{2}{ }^{2}=$ 1,382 , where the chosen significance level $\alpha=$ 0,05 and degrees of freedom $\mathrm{v}=\mathrm{n}_{1}-1=30, \mathrm{v}=$ $\mathrm{n}_{2}-1=30$ using a linear interpolation of observed critical value of the test criteria $\mathrm{F}_{\mathrm{KR} 0,05}=$ 1,671. Thus, true $F<F_{\mathrm{KR} 0,05}$. It follows that among Class 8 year is no statistically significant difference in the average benefit of pupils. A similar process is at the 9th year $-\mathrm{F}=\mathrm{s}_{1}{ }^{2} / \mathrm{s}_{2}{ }^{2}=$ 1,606 , where the chosen significance level $\alpha=$ 0,05 and the number of degrees of freedom $\mathrm{v}=$ $\mathrm{n}_{1}-1=29, \mathrm{v}=\mathrm{n}_{2}-1=28$ in the statistical tables (8) found using linear interpolation critical value of the test criteria $\mathrm{F}_{\mathrm{KR} 0,05}=1,676$. Thus, true $\mathrm{F}<$ $\mathrm{F}_{\mathrm{KR} 0,05}$. From the above again show that the class 9 year is no statistically significant difference in the average benefit.

Equivalence of input knowledge between the two groups - experimental and control classes was verified didactic entrance test. Concurrent validity using Pearson's correlation coefficient was the difference between the initial evaluation of the didactic test and assessment of pupils at the end of the school year. The results could be interpreted that in the 8 th year was $r_{K 1}=0,71$ and $r_{R 1}=0,84$, ie $71 \%$ and $84 \%$ of pupils and in the 9th year was $\mathrm{r}_{\mathrm{K} 2}=$ 0,88 and $\mathrm{r}_{\mathrm{R} 2}=0,89$, ie at $88 \%$ and $89 \%$ of pupils from matching between the input didactic test results at the end of the school year. Based on these data, we can say that between classes and classes is not statistically significant difference.

For the realization of research were established the following working hypothesis:

1. Students applying for teaching project using electrical kits achieve higher performance in knowledge than students taught traditionally without electrical kits.

2. Students applying for teaching project using electrical kits achieve higher performance in comprehension than students taught traditionally without electrical kits.

The actual research was carried out in normal conditions of schools, which is always a group experimental (E1 and E2) were taught lessons of project applications and the second group - the control (K1 and K2) has been traditionally taught. From this perspective have been set up variables - independent variable was teaching method and dependent variable, knowledge, understanding and attitudes of pupils to subject. Validity and reliability of the experiment was ensured by the teacher, classroom and in the control and experimental classes were always discussed the same subject matter for a given year of study.

\section{Testing hypotheses}

Ad 1 students applying for teaching project using electrical construction kits achieve higher performance in knowledge than students taught traditionally without electrical construction kits.

Statistical analysis of the above hypotheses between experimental and control groups is presented in Table 2.

Table 2 Results of analysis for hypothesis 1

\begin{tabular}{|l|r|r|r|r|}
\hline & E1 & K1 & E2 & K2 \\
\hline Arithmetic mean & 9,48 & 8,13 & 10,07 & 8,73 \\
\hline Median $x$ & 9 & 7 & 10 & 8 \\
\hline Systematic variance & 28,46 & 26,30 \\
\hline Random scattering & 2,25 & 2,24 \\
\hline The test criterion $F$ & 12,65 & 11,74 \\
\hline $\begin{array}{l}\text { The critical value of } \\
\text { the test criteria } F_{K R}\end{array}$ & 7,08 & 7,17 \\
\hline Degree of freedom $v_{l}$ & & 1 & 1 \\
\hline Degree of freedom $v_{2}$ & & 60 & 57 \\
\hline $\begin{array}{l}\text { The significance } \\
\text { level } \alpha\end{array}$ & 0,01 & 0,01 \\
\hline
\end{tabular}

The average success rate for pupils E1 was $86,2 \%$ (9,48 points) and K1 students 73,9\% (8,13 points). For the chosen significance level $\alpha=$ 0.01 and for the degree of freedom $\mathrm{v}_{1}$ and $\mathrm{v}_{2}=1$ $=\mathrm{n}-\mathrm{k}=31+31-2=60$ is the critical value of the test criteria $F_{K R}=7,08$. The calculated value of the test criterion $F=12,65$. The critical value of the test criteria $F_{K R}=7,08$. By comparing the calculated $\mathrm{F}$ and $\mathrm{F}_{\mathrm{KR}}$ is the $\mathrm{F}>\mathrm{F}_{\mathrm{KR}}$, and therefore the hypothesis is valid.

The average success rate was at $91,5 \%$ of pupils E2 (10,07 points) and K2 pupils 79,4\% $(8,73$ points). For the chosen significance level $\alpha=0.01$ and for the degree of freedom $\mathrm{v}_{1}$ and $\mathrm{v}_{2}$ $=1=\mathrm{n}-\mathrm{k}=29+30-2=57$ is the critical value of the test criteria $F_{K R}=7,17$. The calculated value of the test criterion $\mathrm{F}=11,74$. The critical value of the test criteria $\mathrm{F}_{\mathrm{KR}}=7,08$. By comparing the calculated $\mathrm{F}$ and $\mathrm{F}_{\mathrm{KR}}$ is the $\mathrm{F}>$ $\mathrm{F}_{\mathrm{KR}}$, and therefore the hypothesis is valid.

It can be argued that students in experimental classes taught by teaching design and use of 
electrical construction kits, achieve significantly higher performance in memory than the traditionally taught students in the control class $\mathrm{K} 1$ and $\mathrm{K} 2$.

Ad 2 Students applying for teaching design through construction kits to reach higher electrical performance in comprehension than students taught traditionally without electrical kits.

Statistical analysis of the above hypotheses between experimental and control group is done in Table 3. It was found that the average success rate was at $81,9 \%$ of pupils E1 ( 8,19 points) and K1 students $63,2 \%$ (6,32 points). For the chosen significance level $\alpha=0,01$ and for the degree of freedom $\mathrm{v}_{1}$ and $\mathrm{v}_{2}=1=\mathrm{n}-\mathrm{k}=31+31-2=60$ is the critical value of the test criteria $F_{K R}=7,08$ ( 9). The calculated value of the test criteria is $F=$ 10,59. By comparing the calculated $F$ and $F_{K R}$ is the $\mathrm{F}>\mathrm{FKR}$ and therefore the hypothesis is valid.

Table 3 Results of analyzes for hypothesis 2

\begin{tabular}{|l|r|r|r|r|}
\hline & E1 & K1 & E2 & K2 \\
\hline Arithmetic mean & 8,19 & 6,32 & 8,10 & 6,86 \\
\hline Median $x$ & 10 & 8 & 8 & 8 \\
\hline Systematic variance & 54,26 & 22,55 \\
\hline Random scattering & 5,12 & 2,00 \\
\hline The test criterion $F$ & 10,59 & 11,27 \\
\hline $\begin{array}{l}\text { The critical value of } \\
\text { the test criteria } F_{K R}\end{array}$ & 7,08 & 7,17 \\
\hline $\begin{array}{l}\text { Degree of freedom } \\
v_{1}\end{array}$ & 1 & 1 \\
\hline $\begin{array}{l}\text { Degree of freedom } \\
v_{2}\end{array}$ & 60 & & 57 \\
\hline $\begin{array}{l}\text { The significance } \\
\text { level } \alpha\end{array}$ & & 0,01 & 0,01 \\
\hline
\end{tabular}

The average success rate for pupils E2 was $81 \%$ (8,10 points) and K2 pupils $68,7 \%(6,87$ points). For the chosen significance level $\alpha=0,01$ and for the degree of freedom $\mathrm{v}_{1}$ and $\mathrm{v}_{2}$ $=1=\mathrm{n}-\mathrm{k}=29+30-2=57$ is the critical value of the test criteria is $F_{\mathrm{KR}}=7,17$. The calculated value of the test criteria is $F=11,27$. By comparing the calculated $\mathrm{F}$ and $\mathrm{F}_{\mathrm{KR}}$ is the $\mathrm{F}>\mathrm{FKR}$ and therefore the hypothesis is valid.

It can be argued that students in the experimental class taught E1a E2 teaching project using electrical kits to achieve significantly better performance in comprehension than students taught traditionally in the control class $\mathrm{K} 1$ and $\mathrm{K} 2$.

\section{Interpretation of results - conclusions}

The validity of the research resulted in claims of working hypotheses on the significance level $\alpha=0,01$ and can therefore accept that with $99 \%$ confidence, the pupils which is applied to design instruction using electrical construction kits, achieve higher performance in knowledge and understanding than students taught traditionally, without electrical construction kits, also can be inferred by the fact that students evaluate the course of instruction follows a much more positive.

The research confirmed the idea that designing instruction, is also supported when the electro kit is actually a very important tool for mediation curriculum just for connecting an emphasis on teaching content and practice.

\section{References}

[1] FRÖMEL, K. Efektivita výchovně vzdělávacího procesu $v$ tělesné výchově. Olomouc: UP, 1987

[2] GRECMANOVÁ H. a kol. Obecná pedagogika I. Olomouc: Hanex, r. 1997. ISBN 80-85783-20-7

[3] HAVELKA, M. Chápání pojmu efektivnost v české a slovenské pedagogické literatuře. $e-$ PEDAGOGIUM, I/2005 [cit. 2011-03-03]. Dostupné na: <http://epedagog.upol.cz>. ISSN 1213-7758

[4] BENČO, J. Ekonómia vzdelávania. Bratislava: IRIS, 2002. ISBN 80-89018-41-6 [5] STRAČÁR, E. Systém a metódy riadenia učebného procesu. Bratislava: SPN 1977

[6] DANIELSON, CH. Teaching methods. Merrill/Pearson, 2010. ISBN 0135130611

Doc. Ing. Čestmír Serafín, Dr..

Katedra technické a informační výchovy

Pedagogická fakulta UP

Žižkovo nám. č. 5

771 40, Olomouc, ČR

Tel: +420 585635813

E-mail: cestmir.serafin@upol.cz, www.kteiv.upol.cz 